\title{
THE ETHNIC THEOLOGY IN THE EARLY BYZANTINE EMPIRE
}

\author{
CHRISTOS TEREZIS \\ University of Patras, Greece \\ e-mail: terezis@upatras.gr \\ LYDIA PETRIDOU \\ Hellenic Open University, Greece \\ e-mail: petridou.lydia@ac.eap.gr
}

\begin{abstract}
In this article we present the general principles of Proclus' ontological system, a topic that is also interesting for how spiritual activities are formed during the fifth century A.C. Specifically, we elaborate one of Proclus' greatest theories, the theory on the intermediate realities as well as the main methodology in which he investigates these intermediates, which refers to the triadic schema "remaining-procession-reversion". Although there is no distinction between theory and the methodology in which it is investigated, since they are in a mutual relationship and are almost identified, we make a distinction between them to understand the Proclean system. So, both the sections of our article have a general theoretical and particularly methodological orientation. The most important aspect that we attempt to show is how through the geometrically structured pyramidal openness of the first Principle these intermediate realities, which exclude the direct communication of the absolute unity of the One-Good with the infinite variation of the natural world, are formed.
\end{abstract}

KEYWORDS: Proclus, intermediates, remaining, procession, reversion.

\section{Introduction}

Proclus the Neoplatonist philosopher (412-485) teaches as the headmaster of the Academy of Athens during the eighth century after its foundation and while reaching the ninth. He writes his works in a period of time in which the philosophical critical-elenchtic-aporetic examination has lost, at least prima facie, its autonomy and authenticity and tends to receive a secondary theoretical mission with respect to how it approaches ontological and anthropological-existential 
questions. By extension, one could contend that during this period philosophy works, more or less, as a useful -and reliable- means for elaborating and structuring -and to a point establishing in arguments- theological and metaphysical topics. It is part of a clearly different cultural (and political) environment compared to that of the classical and postclassical period, in which it followed a quite free and radical development. Reflection has now changed, at least regarding the textual types. This is intensively obvious. According to the new terms and conditions, apart from intra-textual (as self-adjusting) it also becomes metatextual (as adjusted by something else). Every text that is written basically serves a particular purpose, regardless of the special interest that it causes. From a general point of view, the development of the spirit changes during history -not always progressively- while at the same time it concludes the past and in this way it forms its identity as it remains open to new perspectives. Historically, this development is unavoidable, completely justified and can be explained only after it is evaluated both autonomously and as a part of history.

Every historical moment has to reflect in a spiral way the implicit or explicit source of the new things added to it, without this goal being caused by an imperative necessity. Both predictable and unpredictable factors shed light on antibodies or proposals for reconstructions. A more systematic approach, however, leads in that the aforementioned function of philosophy during the fifth century B.C. does not mean that it has suffered a relegation regarding the theoretical values and concerns. It is highly possible actually that the opposite holds true: maybe it is reevaluated at the same time as it deconstructs while using the ethnic acquired of the rest of the theoretical fields. We clearly face a scientific communication in deontological terms, in which sciences are crucial, and by this we mean not only mathematics and physics. Biology and astronomy have presented an impressive performance which exceeds their time. So, the fact that philosophy gets out of its boundaries and penetrates into other disciplines means that it owns or seeks for this sort of possibilities of communication so that it could come into a dialectical debate with them and overcome its self-justifications or its self-erotic integrity. That is to say, the purpose is to exceed its self-reference in which it structures its world, since sciences are endless sources of methodological proposals.

Proclus is one of the greatest ethnic theologians during the early Byzantine era and that is why studying his work is quite interesting for making comparisons between the Greek and Christian thought. This is quite obvious when one investigates him together with Dionysius the Areopagites' treatises. International research has dealt with the matter extensively. ${ }^{1}$ In the following article we shall pre-

\footnotetext{
${ }^{1}$ Cf. for instance, E. Corsini (1962); S. Gersh (1978); B. Brons (1976); E. Ivánca (1953), (1964).
} 
sent the general principles of Proclus' ontological system, which is especially interesting for how spiritual activities are formed during the fifth century A.D. We shall elaborate one of Proclus' greatest theories, that on the intermediate realities as well as the main methodology in which he investigates these intermediates, which refers to the triadic schema "remaining-procession-reversion". We need also to mention at this very beginning that there is no distinction between theory and the methodology in which it is elaborated, since they are found in a mutual relationship and are almost identified. In order, however, to understand Proclus' system, we make a distinction between them.

\section{The "triumph" of the theory of intermediates. Removing exclusions and separations}

Attempting to define in epistemological accurate terms the main scientific and structural question which covers Proclus' work, we could contend that it is clearly metaphysical in its dynamocratic function and that it discusses the divine intermediates and their archetypical nature, which are not considered to be mixed. Therefore, in his view intermediates are those ontological realities and divine powers which intermediate in order some required a priori functions which aim at immanence to take place and strictly structured procedures to be defineddetermined. In fact, these are procedures that make the ontological system not only a dynamocratic organic field of distinctions and unions, well-ordered in a succession with internal dialectical connection, but also revealing a crucial prospect for its aesthetic distinction, which excludes neutrality and mechanism. They exist between the supreme ontological Principle and Cause, that is to say, the completely transcendent One or Good, and the manifold of the sensible beings and, since they are many in number and each one of them has a particular content, contribute to the, justified according to a general reasoning, successive rational organization and function of the entire world. Since they move both in length and width, they form a wavy mobility, which, however, cannot escape the boundaries of that internal structural order which a world with a clear teleological -which means constantly reconstructive and able to improve- orientation has to follow.

We should mention that the historical-philosophical origin of the theory of intermediates is placed in Plato's Philebus, an important work for the reconstructions -or even reversals- that their writer caused to that period regarding his theoretical choices that have to do with the axiological distance between the metaphysical and natural world, a view supported also in the Timaeus. During the dialectical investigation-argumentation, the leader of the Academy intends to identify the exact number of the intermediate ranks as mixtures -here due to the 
dualistic ontological model which is adopted- between two completely opposed ontological levels, that is to say, the unity-uniqueness of the "one" and the distinction-multiplicity of the "infinity", which represents the fertile capabilities of matter, where the question is whether they are inherent or provided. This investigation re-evaluates sensible world on the scale of ontological values, which appears to be a reliable associate of the intelligible, in the context -once again- of a dualistic system -which, however, Proclus actually denies that it was Plato's choice ${ }^{2}$. In fact, through the unwritten doctrines "infinity" represents the "indefinite dyad", which is the metaphysical factor which communicates with matter also structurally and that is why the former reevaluation becomes more intense $\mathrm{e}^{3}$.

The historical development of this inspiration -which had been also mentioned by the Pythagorean circles- reaches its highest point in Proclus' theory, where "infinity" receives a broader meaning and is first and foremost included in the supreme level of the metaphysical world, and together with "limit" compose the two powers of the One in its productive projection, which is revealed through the divine henads. That is to say, "limit" and "infinity" constitute the very One in its participated side, which pass through the henads to the inferior divine beings and, after ontological transformations, to the -non-pre-existing, not even as a

${ }^{2}$ Cf. for instance, In Platonis Timaeum commentaria, II, 381.26-396.26, where the Neoplatonist thinker comments on Plato's Timaeus 30a.3-6. For a systematic approach of Proclus' comments, cf. Ch. Terezis - L. Petridou (2020) 116-16o.

${ }^{3}$ On how Plato structures intermediates in the Philebus, cf. N. Bousoulas (1978). The interesting thing in this book is that he also refers to contemporaneous dialogues, such as the Sophist and the Timaeus, which leads us in the conclusion that Plato systematically discussed this theory and followed a special course to establish it. In fact, if we focus on Proclus' relevant references from the third to the sixth book of his work Theologia Platonica, we will realize that the establishment of the theory of the intermediates comes through all the dialogues of his late period, of course with the unavoidable reconstructions since it was a new approach of the ontological topic, with Plato's Parmenides and its predicates leaving its stamp in the theoretical development. The impressive thing is that, although every time he has to investigate a particular conceptual Platonic code, he manages, by flexibly applying the principles of his system, to draw through the elaboration of all the dialogues the same conclusion, which is a theogonic, in a descending ontological way, reading of the philosophical categories, which are considered as reflecting the internal properties of the One. He also preserves accurately the philosophical breakthroughs that the leader of the Academy introduced and sheds more light on them, making also meta-interpretations which add new dimensions to the relevant discussion. For a brief presentation of the common places that Proclus finds in Plato's dialogues, see for instance in the first book of the above-mentioned treatise, I, 23.13-26.22, a passage quite crucial for what will follow to the end of this six-volume great work. 
material mass- natural world. Particularly interesting -as well as typical of the general tendency- is that the Neoplatonist commentator elaborates in the third book of his Platonica Theologia the pair "limit-infinity" after he has discussed the topic of the divine henads, which are considered to be the direct simple projections of the One-Good and constitute the second One. This is the One that expresses the supreme Principle's intention to reveal -possibly energetically- its self-founding internal properties. Whether henads are beings or powers-sources or even both is a question which is not explained with the proper accuracy, obviously because of the great apophatism that covers the highest metaphysical areas. Nevertheless, the texts lead us to contend that "limit" and "infinity" are the two ways in which henads exist in order to form metaphysical world as a complete not per se but as regards a purpose to be actualized-system. The fact that they might correspond to the pair "one-indefinite dyad" is more than obvious -with Syrianus having already decisively contributed to this theory ${ }^{4}-$, while at the same time their combination appertains to a great plan that includes all beings, from the superiors to the inferiors, in the sense of a spreading multiplying process. For a historian of Philosophy who would like to understand the nature and function of henads particularly interesting could be the props. 113-165 of the theoretical treatise entitled Insitutio Theologica, although their content is quite introductory with respect to the basis.

Extending the above, we would argue that Proclus introduces the following order: it is ontologically necessary metaphysical world to be presented as (self-) defined to receive specific properties, in order to work as an endless productive source of the natural world. This is not, however, a necessity -that somehow sets a limit to the functions of the new reality that it directs-, for any progress takes place is caused by the intentional providence, which is analogously developed and forms a particular ontic field. Besides, not only the One keeps completely unparticipated its nature but also all the inferior divine beings which are successively revealed. In fact, it is not the unparticipation that is decreased, but the participation that is gradually increased. Furthermore, if the divine was subject to necessities its absolute nature would be included in a narrow energy restriction and would fall under manifestations that it would have to perform. Thus, "limit" and "infinity" are the powers that reveal the unutterable way in which henads organize their emanating projection, which is multi-branched and able to define its internal order. All these, so that the powers which will form both natural

\footnotetext{
${ }^{4}$ Considering how Philebus is used in the Theologia Platonica, cf. J. Combès (1987) 177-19o, where Combès investigates how the transcendentally absolute One-Being becomes active causality, under mostly the perspective of the Neoplatonic approach of the Platonic model "limit-infinity-mixed".
} 
world and the necessary eternality to actualize the a priori teleological planning to be structured. So, teleology disproves necessity.

It is to be mentioned that Anaximander's "infinity" preserves its historicalphilosophical validity. Except that Proclus puts together with its endless projections the extreme and unchanging metaphysical "limit" of Parmenides. According to the Neo-Platonist philosopher's texts the relation between the two Pre-Socratic philosophers could be also expressed vice-versa. So, the following exemplifications can be found, the "tool" of which is a conceptual material that shows the development of the Platonic Academy in the field of Ontology. It should be also mentioned that the dialectical combination of the opposites reaches here the highest possible point, as referring to the very same reality, in a way that puts aside simplistic monism at the same time as it reveals monism as a dynamocratic variety which is able to form an analogous immanence with endless multiplica-

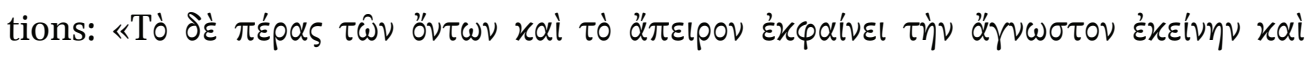

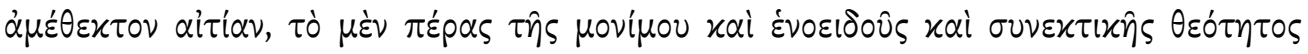

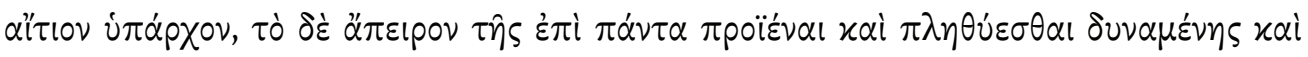

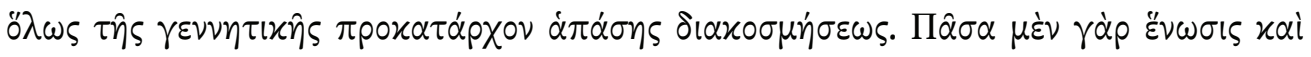

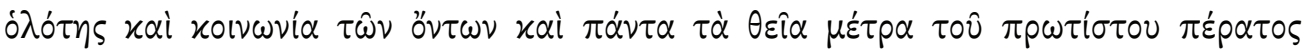

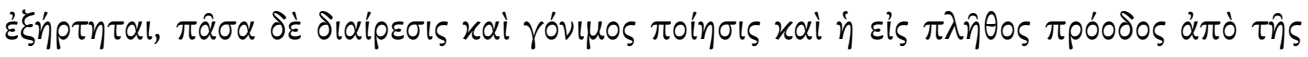

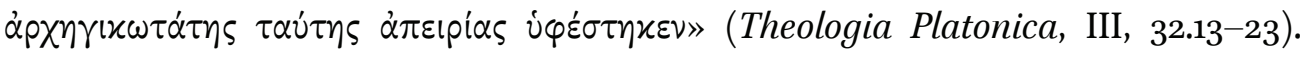
Note that, apart from the metaphysical and, by logical extension, cosmological topics that are presented in this extract, the Neoplatonist philosopher also sheds light on the aesthetic aspect, thereby the whole process of emanation-production is actually described as a revealing of beauty. So, as in any other theoretical attempt, he does not suggest a neutral Ontology and, therefore, "limit" and "infinity" constitute not only ontological but also aesthetic intermediates, ${ }^{5}$ so that to make

${ }^{5} \mathrm{Cf}$. G. Van Riel (2000) 399-414, where we read the following about the relation between the Parmenides and Philebus according to the Proclean approach, which shows the multiplicity and complementarity of the questions which occupied Plato during the last period of his spiritual course: «A vrai dire, $\pi \dot{\varepsilon} \rho \alpha \varsigma$ et $\ddot{\alpha} \pi \varepsilon i p o v$ ne sont pas totalement absents du Parménide. L'illimitation de l'Un figure dans la première hypothèse, mais ce n'est que pour indiquer, dit Proclus, que l'Un dépasse toute limite et même toute

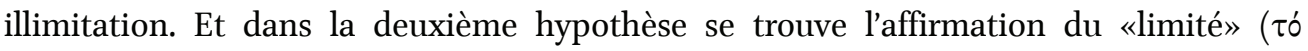

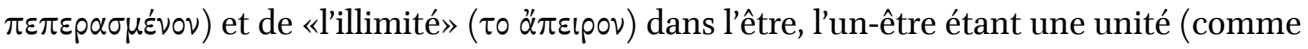
$\left.\varepsilon^{\prime \nu}\right)$ ainsi qu'une pluralité illimitée (comme ơv, comprenant tout ce qui "est"). Mais dans ce cas-ci, les caractéristiques indiquées ne jouent pas du tout le rôle compréhensif qu'elles reçoivent dans le Philèbe. Il ne s'agit pas ici des principes eux-mêmes, mais plutôt des éléments dépendant des principes (appartenant donc aux séries verticales susdites)» (407). These are crucial comments for the intermediates and lead us to investigate whether we can put "limit" and "infinity" between the first two hypotheses of the Par- 
possible a positive evaluation of the relevant, which has to act in a mimicparticipating way. And obviously, the aesthetic aspect is closely related with personal actions and reflects inner conditions of freedom. This extract is however interesting for some other references as well. First of all, it is interesting because the supreme Principle does not appertain to human cognitive range, since it is unparticipated and, therefore, not subject to any kind of relation Apophatism is both gnoseological and ontological. Secondly, it is interesting because the relation between the produced beings is mutual, both uniting and distinctive. So, generally, this is a system full of determinations, well-ordered one another, regardless of the opposition, both in depth and width, with the hypostatic particularities beings explicit.

Proclus considers intermediates as metaphysical archetypes both when related one another (superior-inferior in the context of a geometrically organized hierarchy, where the relation "monad-arithmetic multiplication" is also developed) and when related with the sensible beings, those which fall under becoming. He elaborates the relevant theory in detail mostly in the work written during his spiritual maturity entitled Theologia Platonica and associates it with the content of the ontological categories of the second hypothesis of the Platonic dialogue Parmenides, under constantly a Neoplatonic meta-interpretation. It is to be mentioned that this dialogue historically is the first systematic treatise in Antiquity which discusses successively a whole of ontological categories, which can be considered as descriptive of the way in which "being" exists as the leading category and the first that comes into relation with the "one", the participated side of the supreme Principle. Furthermore, these are categories that define the multiple levels of the relations developed between particular beings and this is why they show a system of dynamic functions or transition of energetic fields, including the different modes that this sort of developmental ontological condition necessarily causes. ${ }^{6}$ Note, however, that in the Platonic text no hierarchy between the ontological categories is found.

Furthermore, the fact that these categories turn into divine intermediate realties is, as constantly is proved, a Neoplatonic innovation, in the context of how its

menides, so that they can be connected. Thus, the categories of the Philebus will turn into functional links in a relation that is not easily explained but is accepted as objective. The One of the first hypothesis of the Parmenides is considered essentially as infinite, since it exceeds any "limit", is unparticipated and gnoseologically absolutely transcendent. It is completely out of any discussion, which, any time it is made, proves that it should have not been done and that is why it is disproved.

${ }^{6}$ For a general approach of this topic and with crucial references to the question of space, cf. E. Moutsopoulos (1982) 419-433. 
exponents attempt to establish a multi-cause system so as to show that the successive structure of the Platonic dialogue represents forms of causality, which generally are specific in number -at least as to their universal appearances- and personally intentional. Specifically, according the philosopher from Lycia, the intermediates are divine realities, which express through their presence and activity the former exodus of the One from itself and the gradual exemplification of the productive function within defined theogonic and providing-being triadic procedures, where each "three" constitutes a reversion of the "two" as a development to the "one" as a principle, and, therefore, its somehow restoration and completeness. In this sense, he describes a system of successions, which follows a particular ontologically inferior logic of development, which has to be approached carefully. The rationale has to do with the explanation of the reasons why a category-god comes before another and a next one follows. Note also that according to Proclus the system of categories is quantitatively unspecified, for every divine category endlessly multiplies itself. Therefore, every category presents an infinite variety of specialized meanings, which denote functions and forms. Note also that these multiplications expand, in the sense of an infinite calculus, for they are involved with the multiplications of the other categories with countless traversal procedures.

We need to clarify that although the terminology used in many cases by the Neoplatonist philosopher in his texts changes, the main principles remain the same. Or, it is possible that the same characterizations are used for the same ontological level, depending on the functions-relations that according to him it develops. Nevertheless, variety is due to the fact that the theoretical sources are multiple, which do not come exclusively from the Platonic corpus. Eclecticism is impressive. A typical example is the category of the Intellect, which according to Proclus' argumentation corresponds to the intellectual gods, and, when related to the Platonic dialogue Parmenides, includes the categories of the internally op-

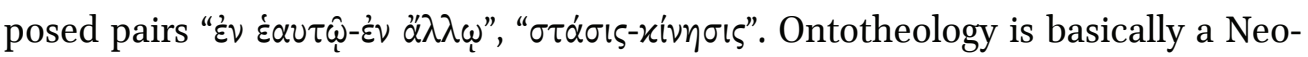
platonic product and possibly is completely absent from Plato, since he had not even imagined successive theogonies. Presenting the structural-functional characteristics of this category according to his own theory, Proclus contends the fol-

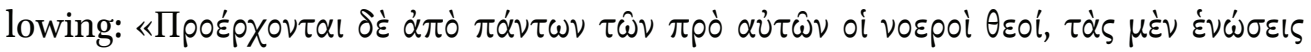

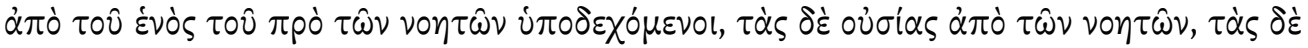

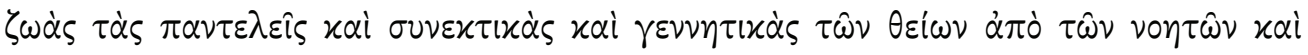

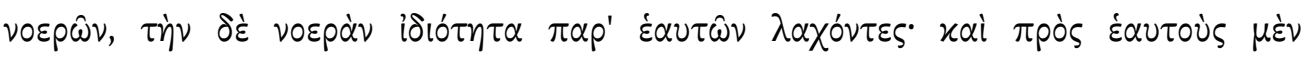

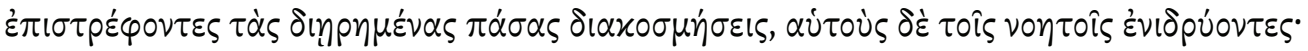

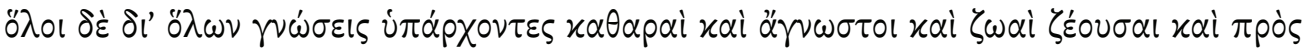

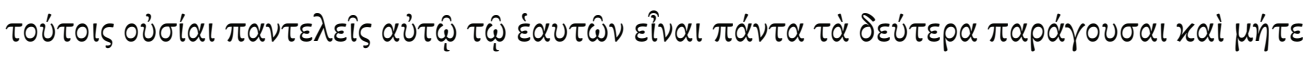




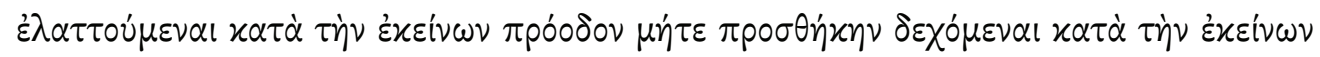

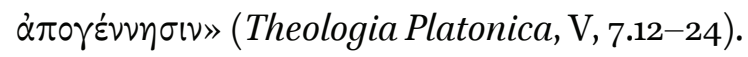

Commenting on this passage -which is one of Proclus' most innovative-, we would contend the following: Taking into account the theory on intermediates, it is interesting that every category-divine being comes from emanations and works as the source of new emanations, while at the same time it contributes, together with the superior entities, to its formations, so the possibility of passive assimilative conditions is out of the question. So, causality is proved to be composite. Therefore, due to the fact that every divine being is naturally metaphysical, it owns the property of self-constituted as well, which excludes absolute dependence and emphasizes the dialectical relationship of the initiatives of both that who provides and that who receives. Furthermore, the mutual coexistence of intermediates is typical, without any violation of their hierarchical structure, which from any point of view is based not on dominations but on the range of the properties given. Their main function, however, is that they constantly refer to themselves and reverse to their superior beings, so they preserve the principle of continuity in the metaphysical level, which, regardless of its development, does not violate its self-founding nature. We need to mention that Plato had remained to the formation of an integral metaphysical Ontology, which however provided a different compared to that of the Neoplatonists explanation of the intermediates, where there is no process of "reversion" as a -metaphysical- self-confirmation. Through his unwritten doctrine of "one-indefinite dyad" he clearly raised hierarchy questions -as he did in the Parmenides-, in the sense exclusively of an ontological spread. Note also that Proclus bases his Ontotheology on the categories of Philebus "limit" and "infinity", to which he adds an authentic ontological and divine content and considers them as the powers of the One-Good, as the ways in which every divine being is successively formed. Neoplatonic monism defines different regularities compared to those which Platonic dualism defines.

\section{The triadic schema "remaining-procession-reversion"}

It is to be mentioned that the externalization of the One mentioned before takes place to a point and does not reveal completely its absoluteness, which in the former text is presented as not subject to any relation. This is clearly a theological subject-matter, which the Neoplatonist philosopher discusses mainly with an as much as possible apodictic argumentation in -the unquestionably theologicalsecond book of his treatise Theologia Platonica. Nevertheless, the tendency of the One ad extra is not discussed only in general references, but is also presented as unfolding through procedures, which follow a general rationale of how distinction works within the inviolable unity. These procedures follow the principles of 
the triadic dialectical emanating-productive schema "remaining-processionreversion". The level of "remaining" shows the remaining of the Supreme Principle as well as any other secondary principle in them, in an absolute condition of unparticipation and somehow inner self-determination. It is the point which reflects the authenticity beyond any relation, at least regarding external dependencies. J. Trouillard says: «La première fonction est assurément la plus mystérieuse. Elle est, en effet, le moment non processif de la procession, l'immobilité centrale du cycle automoteur, l'unité qui soutient toute multiplication. A ce titre elle porte le mystère de l'Un au coeur des êtres» (1972, 91). The emphasis on the mystical character of "remaining" does not remain in the insuperable transcendence of the One. It extends, since it is established as an analogous state in a descending somehow proportion in the very inner world of the divine produced beings. Multiplicity does not exclude unity, it owns it as an a priori "unnegotiable" property and, thus, in order to work according to its ontological founding, it has to be constantly ready to be actualized, which will also work as a self-confirmation for it. In other words, movement has to explain standstill, so that to gain, at least to a point, self-movement, which contains both conditions in a dialectical combination, which results in some surviving evidence in Aristotle ${ }^{7}$. On how metaphysical world develops, however, Proclus uses the term "procession".

The second level of the triadic schema, "procession", represents the emanation-production of the -metaphysical and natural- effects coming from the supreme Principle and their secondary-direct causes, from its participated side of their hypostasis. This is a descending process, which, in order to function, has to follow ontological descending terms, so that the productive goals that have been originally defined to be accomplished. In this course towards multiplicity the function of similarity is revealed, which does not only prove similarity but also distinction, which is of that kind that not only preserves from inflexible identity

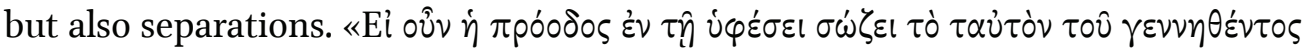

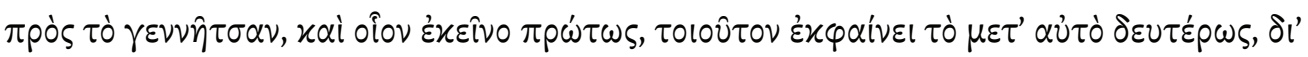

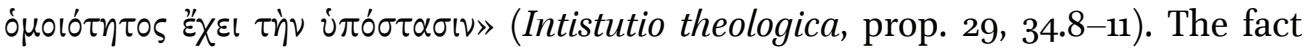
that similarity does not only reveal similarities and differences but has also an explicitly ontological content is more than obvious. Originally is basically defined as contributing to new productive events, and shows the inner dialectics of every cause, how from its self-reference will come to its externalization. Finally, the level-process of "reversion" reveals a return of the particular effect to its direct

${ }^{7}$ Cf. for instance the book K of Metaphysica and the eighth of Physica, Cf. P. Aubenque (1991) 413-456, where with a particularly precise choice of texts, the relevant discussion elaborated by the philosopher from Stageira is presented. Regarding the relation between movement and the lack of movement, cf. the great book of S. Gersh (1973). 
cause and through it to all the former ones and eventually the One, in order to be ontologically complete and to get the requirements to function also productively, in absolutely conscious terms.

We need to emphasize that the dynamocratic sense of initiative concerns every metaphysical being, so we could argue that there is a formation-or even preexistence- by analogy of the consciousness as communication, which actualizes not in terms of necessity but freedom and successively unity, both by level and all in all. On the other hand, similarity is important in the process of reversion:

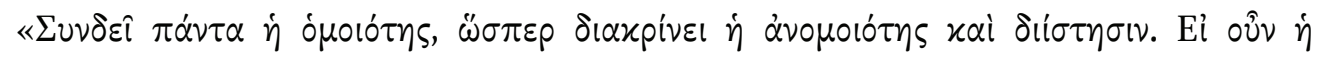

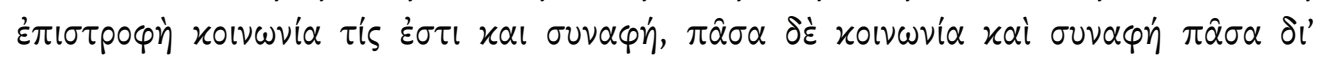

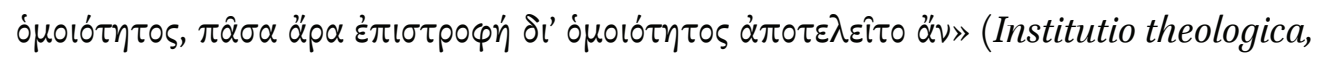
prop. 32, 36.6-10) $)^{8}$. There is not violation of the self-founding regularity in the metaphysical world. Nevertheless, here as well, a special teleology develops, in the sense that every divine being which reverts to its causes acquires completely that perfectness which corresponds to it, at the same time as it contributes to the general also self-founding perfectness. ${ }^{9}$ Basically, this is a sort of teleology, which accomplishes unity in multiplication terms. In this direction, special attention is required in that an effect relates in a particular way with its direct case, without violating its unparticipated part, so that the a priori original nature of unity to be preserved from every respect, which gives meaning to any procedure, so as to avoid essential changes. Any diversion from the "logic" of unity leads to a decomposing intervention of dissimilarities and differences, that is, to the unnatural in opposition to the self-founding. So, in order unity to be preserved, we could argue that the effect exists, before to come into existence, into the participated part of its cause.

\footnotetext{
${ }^{8}$ According to E. R. Dodds (1933) 219, likeness is the condition of "procession" (cf. prop. 29), so it is also the condition of "reversion". With no doubt, Proclus here had in mind the Theaetetus $176 \mathrm{~b}$. Furthermore, likeness is the condition of knowledge and knowledge is a sort of "reversion". Note also that likeness is the principle on which theurgy depends for its theoretical possibility. The content of this proposition as a doctrine has been also used by Dionysius the Areopagite in his De divinis nominibus, 9.6.

${ }^{9}$ For instance cf. the following definite remark of W. Beierwaltes (1979) 124, which reflects the leading actualization of metaphysical self-reference: "Hervorgang ist, als simultaner Akt gefasst, immer schon Rückkehr in den Ursprung, wie die Rückhehr sich nur in dem und durch der Hervorgang aktuiert und das Verharren sich nur in und durch Hervorgang und Rückhehr als denkende Bewegtheit zu begreifen vermag. Der Akt des doppelten Vermittlung : Entfaltung und Rückgang des Geistes in sich belst, vollzieht sich als Kreis".
} 
However, the Neoplatonist philosopher has already made this comment. J. Trouillard summarizes in precision -raising also interpretative questions- Proclus' reasoning, relying on the propositions 30 and 35 of his Institutio Theologica, which reveal internal dialectical aspects, which appear in many ways: «Si la procession exige la manence du principe en lui-même, elle, requiert logiquement une manence du dérivé dans le principe. Et la procession est d'autant plus puissante que cette présence est plus parfaite. Pourquoi la procession s'accomplit-elle par une conversion qui, loin de l'annuler, la sauve de la perte dans l'océan de la dissemblance? C'est que procession et conversion sont fondées toutes les deux sur un point de cö̈ncidence indissoluble entre générateur et engendré» (1972: 98). The teleological example, which appears through a number of intentional and conscious modes, is more than obvious in these comments. An erotic relation between those beings which associate one another in terms of active causality is their leading existential goal, which from every respect forms creativity, which necessarily comes through self-reference, which is also considered as a discovery of the gifts. That is to say, any production requires its body to turn to itself, where he discovers his sources and takes the responsibility to repeat them. It is to be mentioned however that the source of the productive process, regarding what gnoseologically takes place, functions as "self-contemplative thought", in order not to be obliged to acquire knowledge from what is produced. That is to say, its cognitive plenitude should not be defined ad extra, though it does not produce to gain consciousness of its creative selfhood. It possesses this consciousness originally and this is exactly what it confirms through "reversion".

Note that Proclus hierarchizes intermediates by following an ontological priority -or the transcendent purity- of their substance, an order which also defines the range of their productive-archetypical nature. In this way, it becomes clear why they are not just the productive archetypes of the sensible beings but also, and basically according to what metaphysical rationale, how they work in an archetypical way in their relationships. The superior ones constitute the archetypes of the inferiors. It is to be mentioned that this hierarchy is considered as the absolute result of the One's planning, which activates the inferior gods in order to take part in both the projections and the transitions with respect to the emanativeproductive particularizations. Generally, Proclus' theory on intermediatesarchetypes is included in the metaphysical orientation -as well as those that justify Cosmology- of Neoplatonism and, more specifically, reflects the philosopher's intention to answer questions that his School dealt with, which are mostly related to the philosophical-theological -or, more accurately, henological- explanation of the content and the relation between the hypotheses of the Platonic 
Parmenides $^{10}$. Specifically, how from the unparticipated One-Good the entire world is produced through the intervention of the second One or the "onebeing"."

In this process, what dominates is the ontological-logical schema "onemultitude", the branches of which present endless combinations and structures, defined by monads as special appearances of the "one", which have a clear originally integral nature, which first and foremost is the source of metaphysical combinations, and interfere so as to contribute, according to their responsibility, to the formation of general core structures of the sensible world. The Neoplatonist philosopher describes this productive development in many ways and names in all

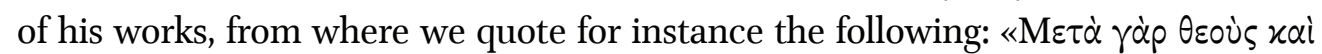

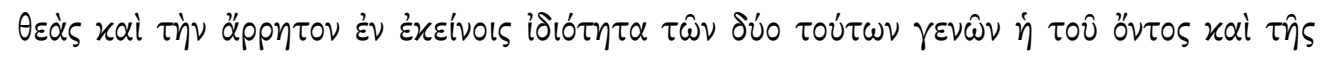

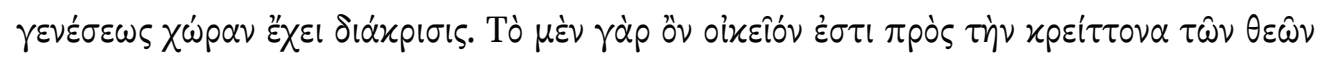

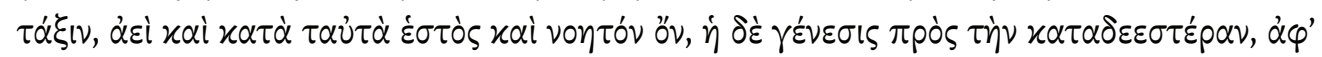

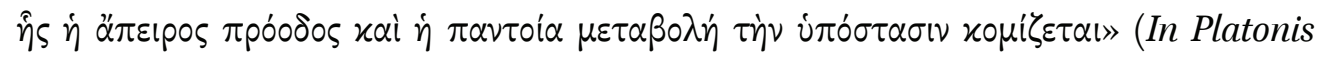
Timaeum commentaria, II, 224.11-17). The traditional distinction of the Platonic Academy between "being" and "becoming" defines the positions-functions of the two worlds, while at the same time it defines analogously the gnoseological ones so that to ensure the requirements which will determine the causal transitions as pos-

\footnotetext{
${ }^{10}$ On how Proclus utilizes -actually, interprets- the dialogue Parmenides, cf. H. D. Saffrey - L. G. Westerink (1968-1997) v. I, LX-LXXXIX and v. III, XVII-LI, where the whole discussion is presented through a combination of extracts from his treatises In Platonis Parmenidem and Theologia Platonica, while at the same time they present the relevant historical-philosophical tradition. In the third volume the two scholars, motivated by an extract from the In Platonis Parmenidem (1049.37-1050.25) about the unity and distinction of the henads, contend, taking into account also the proposals of late Neoplatonism, which combine Ontology with Logic: «Avec ce dernier texte, nous tenons en effet la manière dont Syrianus et Proclus lisaient la deuxième hypothèse du Parménide. Ils la décomposaient en quatorze parties, "selon ses articulations naturelles". Chaque partie contient un syllogisme conditionnel, introduit par la prémisse, toujours la même : "si l'un existe". Cette prémisse peut être exprimée ou sous - entendue, elle n'en demeure pas moins présente dans chaque argument. Le syllogisme aboutit à une conclusion qui varie chaque fois et qui établit une propriété de l'être, propriété qui est caractéristique d'un degré des êtres. Ces propriétés, se déduisant les unes des autres, fournissent dans l'ordre naturel la procession continue des divers degrés des êtres» (XLVIII-XLIX). A system of individualities is here presented, which under the process of tansition formes an ontological hierarchy, from superior to inferior beings, a firm structurally schema which founds the terms of its argumentation. So, ontological individualities 'seek for' their intellectual exemplifications.

${ }^{11}$ Regarding the second One, cf. E. R. Dodds (1933) 258-259; P. Hadot (1968) 303-307.
} 
sibly energy transmissions, as the source of changes, which should be considered as negative conditions. As theophanies, they are related with teleology.

Considering the triadic procedures and relations, we could contend that they are discussed by Proclus as components and structural elements of the divine world and as the requirements for its completeness. They constitute an inviolable dominant principle, which is actually an ontological one, so that it can define the true and coherent relationships. It is to be mentioned that these do not result in transmissions, but in that the triadic relations are a way, in an original sense, in which the divine beings exist, which are actually connected one another. What is more, a triad completes the pair "one-indefinite dyad" of the first period of the Academy and gives decisive answers to some ontological questions that had to do with development. The One provides in a triadic dynamocratic -namely, exemplified- way to the divine beings ontological hypostasis. First and foremost, it includes them as seeds, subsequently, after an externalization from itself, it brings them into being -in an particular for each one way, so as to avoid any inflexible and non-contributing to development identities-, and, finally, it makes them to reverse to it, in the sense that they utilize in their own way and completely consciously what they have received. Note that all these take place regardless of the natural categories of time and space and they somehow represent a selfdevelopment of an already existing originally ontological energy field. Next, the divine beings are produced in triads, they produce themselves and they produce new beings following the dialectical schema "remaining-procession-reversion" as a self-development from a condition to another under the general transmission schema from union to distinction. It is a process which can be characterized as dialectical, for it moves through self-references, so that to develop communications with other conditions. This ascent takes place only after they exceed themselves. The transition from a point to the next one occurs not mechanistically but through an intentional tendency for grows. Thus, any sort of necessity, as introducing some restrictions, is excluded, as a necessary stage for strictly specific and non-intentional projections. Furthermore, the ontological field does not change after coming out from "remaining" and developing to the "procession", for it is contended that anything takes place due to hyper-sufficiency, at the same time as the "reversion" proves the transcendental "strength" and the "assertion" of absolute significations.

This triadic model of emanation-production allows detecting the variety of the relationships developed between Proclus' divine entities as well as their ontological, functional and axiological classification and exemplification, with the latter one being also found in their effects. This is a sort of monism which owns universal characteristics, including both the essential and the structural elements 
through the -actually non-typical- repetition of principles that have been already formed as regulatory starting points. One could find here an interesting parameter for highlighting individuality regardless of the strict terms of regularity, which are defined by a theoretical attempt that aims at making it a system. We would be theoretically valid if we claimed that the example, or the goal, of a coherent theory is more than obvious. We have already proved that similarity is a global constant, which also causes separating modalities. In fact, in every being or category we also find the rest as -defined by a particular function in each caseproperties, so we could say that similarity reveals the various ways of this coexistence. Therefore, the metaphysical system is subject to a former relegation not in itself but as regards the ways in which it chooses to manifest- and, when this multiplicative processes come to an end, the requirements have been formed -which are also characterized as "natural reasons" in order the sensible world and its functional variety to be structured. ${ }^{12}$

${ }^{12}$ On the schema "remaining-procession-reversion" in Proclus, cf. Institutio Theologica, prop. 25-39, 28.21-42.7. E. R. Dodds (1963) 212-223. J. Trouillard (1972) 78-106 and (1982) 53-91. W. Beierwaltes (1979) 118-164, where we read the following, which are related with the principle of unity and the analogous degree in which it is successively actual-

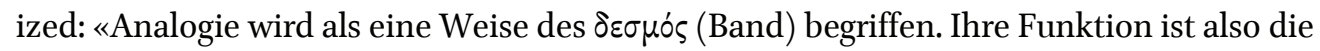

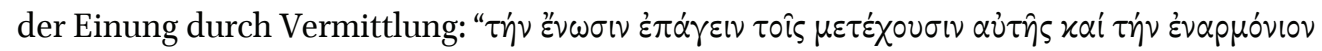

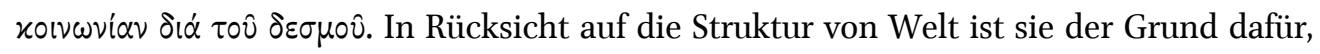
dab diese eine mit sich selbst vermittelte Einheit ist. Diese mit sich selbst vermitteltre Einheit vermag Welt jedoch nur zu sein, da sie nach Vollendung strebend "analogisch" in die ursprunghafte Einheit, das Eine selbst, zurückgeführt und von ihr her begriffen wird. Analogie ist also der Grund der einheitlichen Struktur und ebenso der einheitlicken Bewegtheit von Welt in ihren Ursprung. Das Mabgebende für die Analogie als Struktur- und

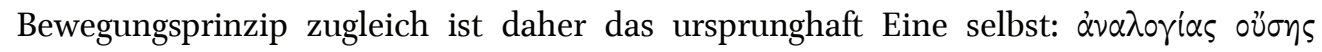

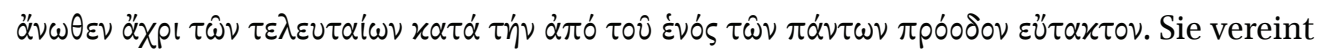
die Extreme der Welt zu einer einheitlichen Ordnung. Durch das im Entsprungen- Seienden monadisch gegenwärtige Eine wird also das Seiende selbst dem Einen analog: " $\tau \hat{\omega}$

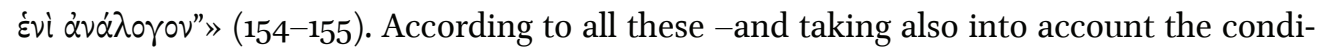
tion formed by participation-, we would contend that Proclus can be easily characterized as the patriarch of the principle of analogy, by which the degrees of unity are defined, in a system that experiences a processional ontological relegation, for reasons however that it sets and which do not violate the integrity of the first Principle, but represent how great it is even when it exceeds itself. Furthermore, we should not ignore that throughout the entire comment he mentions the structural factor and the aesthetic order that it provides, so mechanistic perspectives or a neutral Ontology are out of the question. 
The general rationale found here is that it is not ontologically feasible and logically justified an absolute multitude to arise from complete unity without middle procedures. This process could work in the sense of a mechanism of automations, which would eliminate -or would make scientifically easier- any question on procedures-modes, which either way cannot be thought independently from transformations, which are defined according to a special orientation, in order to explain, as far as possible, the connection of those which are separated. The text does not allow a condition of " $\xi \xi \alpha i \varphi v \eta s$ " (sudden and unexpected). Thus, the ontological requirement is to form a somehow metaphysical multitude, which would found, not actually with precise mechanistic parallels between the terms, the natural. Do note that an analogous formation of ontological requirements has been already expressed through the dogma of "indefinite dyad" of the first period of the Academy, a theory which made easier -and added theoretical validity tothe combination of those which appeared firstly as opposites, regarding mostly the structure of the metaphysical world. So, the final conclusion is that the metaphysical world forms a multi-centric and defined in precision system. Otherwise, any development is not possible, which, however, cannot be considered as a threat against monism, which contains complete terms of self-foundation, which means that it can define any sort of action.

On this, J. Trouillard, presenting the polymorphism of the particularities of the metaphysical world, mentions the following: «Chaque être véritable est son propre démiurge, mais sous l'illumination des démiurgies plus concentrées et plus puissantes. Ainsi les différences entre les êtres se ramènent à des proportions variées de manence et de procession. La procession se diversifie en modifiant son écart et sa réintégration, c'est-à-dire le circuit qui constitue chacun. Elle ne s'avance ni par bonds discontinus ni en linge droite. Mais par une reprise incessante de son point de départ elle glisse de totalité en totalité selon un schéma hélicoidal fait de progression et de régression» (1982: 112). Having in mind that Proclus proposes a consistent universal eternity, it becomes clear that every metaphysical whole includes the internal order of the unity, since, without this, it loses its hypostatic particularity and, by extension, it would be unable to participate in the production of the sensible world relying on its projections. Considering the structure, we need to focus on the fact that Proclus stresses the spiral development of the metaphysical world, since coherence and mutuality of the archetypal particularities, both naturally and with respect to their productive projections, are definite. Spiral means mostly kinetic projection, in a new utilization, of the already existing elements -as formed ontological conditions-, which need to understand their new position in the successively formed for the first time ontological fields and to functionally adjust appropriately. Thus, their inter- 
vention is constant during the development, a function which reveals the general flexibility of the system to cause new somehow modes. In sociological terms, this is a combination of the traditional with the progressive element, in the sense of a complete awareness of those great things that will appear in a sensible way and will reveal the beauty of their sources as well.

To actualize these dynamic schemata, there is one more strong cause which has to do with the fact that every metaphysical being is also self-constituted, in the sense that it activates anything it receives, in order to be formed as a particular and unique being in its own way. So, since it owns the initiative which constantly corresponds to it, it becomes capable of being present in decisively interacting way to all the spiral formations. However, we should not ignore that, despite its common presence, it is a particular being which does not face relegation or distinction after it has participated in the production of another being. To understand the process of the ontological development in the sense of a dominant unity which is universally inviolable, we need to keep in mind that it is not interrupted by anything and it is flexible. Otherwise, egoistic isolationism would arise. Therefore, we are speaking of a cosmic system that revolves around itself, which the Neoplatonist philosopher discusses in detail in his commentary on Plato's Timaeus, which does not fall under necessity but functions freely. Selfconstruction means the beginning of a conscious presence and projection, which makes metaphysical world receiving a personal dimension as well. ${ }^{13}$

The following passage from this treatise refers to the function of the Soul, which provides the natural world with properties, both generally and particularly, in the sense obviously of a rationality which includes all the seeds, with the pro-

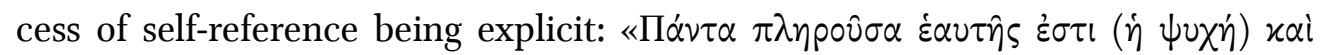

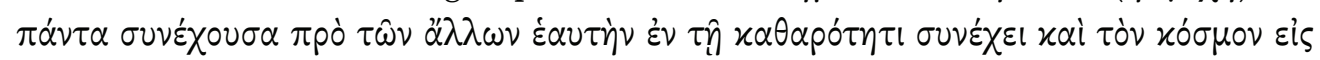

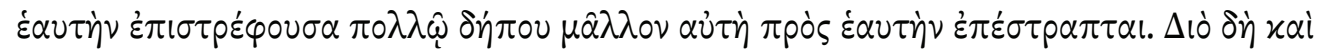

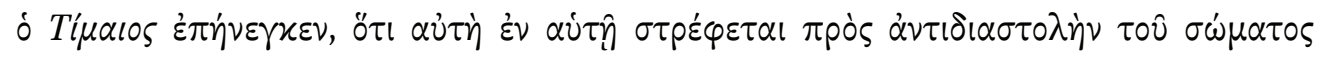

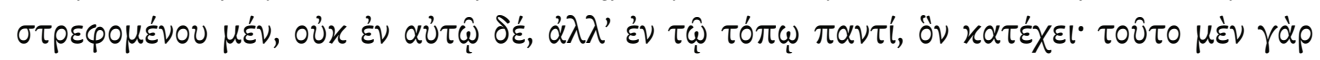

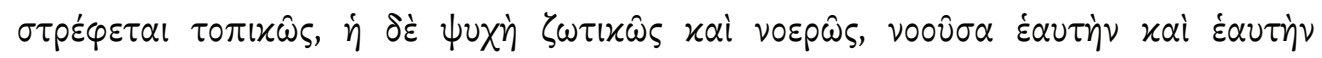

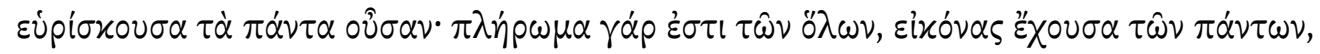
äs $\theta \varepsilon \omega \mu \varepsilon \dot{\varepsilon} \eta \eta$

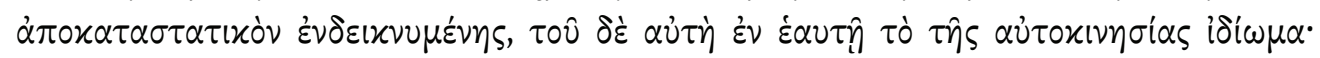

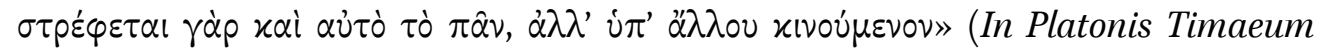
commentaria, III, 286.8-22). Regardless of the differences between the natural

\footnotetext{
${ }^{13}$ On the concept of "self-constituted", cf. Institutio Theologica, props. 40-51, 42.85o.6. Cf. also, E. R. Dodds (1933) 223-227 J. Trouillard (1972) 76-77. Ch. Terezis (1986) 9o97. According to Proclus, the "self-constituted" are divine beings that correspond to the categories of the second hypotheses of the Parmenides.
} 
bodies and the Soul, which affects them in endless ways, the spiral nature of both the Soul and its superior metaphysical powers is stressed, which it possesses and uses depending on the case, which requires that this intermediate reality has referred to itself. It already knows what will follow through its sudden selfreference. Being itself exists with its self-awareness. Ontologically, the Soul is the intermediate factor which makes metaphysical world immanent, without however violating its integrity. It obviously particularizes in practice its energy explosions. Finally, speaking of turns the view on eternal rotations of the natural world is discussed. These are rotations or twistings, which, due to the certainty of their sources, are gnoseologically founded. Nothing happens randomly and the natural world receives personal qualities, through the reference to space, in which the intelligible archetypes are sensibly formed (that is to say, through sensible beings). The fact that the style is metaphorical reflects the expressive realism, which is adjusted to how metaphysical procedures, which human cognitive ability cannot completely understand -or understand to a limited extent- are approached.

\section{Epilogue}

Everything we elaborated composes the basic foundations on which Proclus establishes his general theory on the somehow multiplicative development of the metaphysical world. This is a development which he builds to justify the multitude of the sensible world. Having as his main theoretical direction the fact that the natural world is completely dependent on the metaphysical one, he focuses on how he will present the latter as the cause in terms that they found the former as an effect. Thus, following and extending the attempts of his predecessors Neoplatonists he explains the divine multiplication which will form the general ontological categories on which the production structures of the natural world will rely. Both the sections of our article have a general theoretical and particularly methodological orientation. The purpose is to form through the geometrically structured pyramidal openness of the first Principle those intermediate realities which will exclude the direct communication of the absolute unity of the OneGood with the infinite variation of the natural world. Therefore, this development -or, openness- constitutes a necessity, which however -as Proclus analyses mostly in his commentary on the Timaeus - takes place in an intentional and personal way. There is no suspicion of automatism or mechanism.

Generalizing our rationale, we need to stress that Proclus in his Institutio Theologica systematically forms the principles of what we elaborated, while at his sixvolume treatise entitled Theologia Platonica he specializes them through the particular gods of his system. Composing these two words, we could refer to a multiplication of the One and a unification of the multitude. The former is performed 
through "procession" and the latter through "reversion" In any case, however, "procession" does not affect that the result is eternally present in the "remaining" of the cause as well as that "reversion" is also an eternal condition. Therefore, this is a non-transitional process which develops any divine intermediates are required - which pre-exist within the One- for the production of the natural world. These have been elaborated by Al. Kojève (1973). The most important thing in this study is that the writer manages somehow to show the infinite in number way of the development of the metaphysical world. This is a development which he presents arithmetically in its original formation -that is to say, regarding the general principles-, while at the same time he has presented also schematically showing that after all we are not able to completely adjust all the metaphysical levels.

\section{REFERENCES}

Aubenque, P. (1991) Le problème de l'être chez Aristote. P.U.F., Paris.

Beierwaltes, W. (1979) Proklos. Grundzüge seiner Metaphysik. Frankfurt am Main.

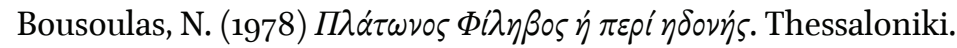

Brons, B. (1976) Gott und die Seienden. Untersuchungen zum Verhältnis von neuplatonischer Metaphysik und christlicher tradition bei Dionysius Areopagita. Göttingen.

Combès, J. (1987) "Les trois monades du Philebe selon Proclus", in: J. Pépin and H. D. Saffrey, eds. Proclus lecteur et interprète des Anciens. Actes du colloque international du C.N.R.S. Paris, 177-19o.

Corsini, E. (1962) Il trattato "De divinis nominibus" dello Pseudo-Dionigi e i commenti neoplatonici al Parmenide. Publicazioni della Facoltà di Lettere e Filosofia, Torino.

Dodds, E. R. (1933) Proclus. The Elements of Theology. Clarendon Press, Oxford.

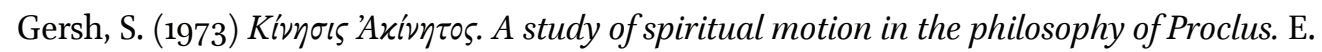
J. Brill, Leiden.

Gersh, S. (1978) From Iamblichus to Eriugena: An investigation of the prehistory and evolution of the pseudo-Dionysian tradition. E. J. Brill, Leiden.

Hadot, P. (1968) Porphyre et Victorinus, v. I-II. Études Augustiniennes, Paris.

Ivánca, E. (1953) "Teilhaben", "Hervorgang" und "Hierarchie" bei Pseudo-Dionysios und bei Proklos (Der E. Ivánca, "Neoplatonismus des Pseudo-Dionysios). Actes du XI ${ }^{\text {eme }}$ Congres International de Philosophie, Bruxelles Voll.XII. [oder (1954) «Der neue Sinn von "Teilhaben", "Hervorgang" und "Hierarchie"», in: Plato Christianus, Übernahme und Umgestaltung des Platonismus durch die Väler. Einsiedeln-Switzerland, Johannes Verlag].

Kojève, Al. (1973) Essai d'une histoire raisonée de la philosophie païenne, vol. III. Paris.

Moutsopoulos, E. (1982) «La structure de l'espace chez Proclus», Revue philosophique 2, 419-433.

Saffrey, H. D. - Westerink, L. G. (1968-1997) Proclus, Théologie Platonicienne. v. I, LXLXXXIX and v. III, XVII-LI. Les Belles Lettres, Paris. 
Terezis, Ch. - Petridou, L. (2020) "The metaphysical "monistic" approach of the Platonic Timaeus by the Neo-Platonist Proclus", Journal of Ancient Philosophy 14/1, 116-160.

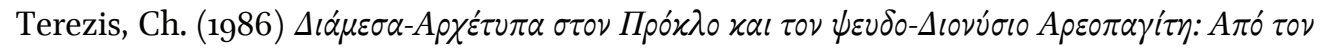

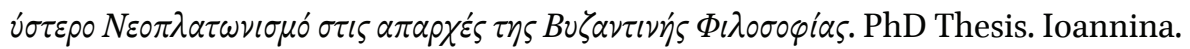

Trouillard, J. (1972) L'Un et l'âme selon Proclos. Les Belles Lettres, Paris.

Trouillard, J. (1982) La mystagogie de Proclos. Les Belles Lettres, Paris.

Van Riel, G. (2000) «Ontologie et théologie. Le Plilèbe dans le troisième livre de la Théologie Platonicienne de Proclus», in : A. Ph. Segonds and C. Steel, eds. Proclus et la Théologie Platonicienne. Les Belles Lettres, Paris, 399-414. 